Kumawula, Vol. 4, No.1, April 2021, Hal 165 - 176

DOI: https://doi.org/10.24198/kumawula.v4i1.32453

ISSN 2620-844X (online)

Tersedia online di http://jurnal.unpad.ac.id/kumawula/index

\title{
PENINGKATAN KAPASITAS DALAM PEMASARAN ONLINE BAGI PELAKU USAHA KECIL YANG TERDAMPAK KONDISI PANDEMI COVID-19
}

\author{
Soni Ahmad Nulhaqim ${ }^{1 *}$, Hery Wibowo ${ }^{2}$, Maulana Irfan $^{3}$, Arie Surya Gutama ${ }^{4}$ \\ ${ }^{1}$ Pusat Studi CSR, Kewirausahaan Sosial dan Pemberdayaan Masyarakat \\ ${ }^{2}$ Pusat Studi CSR, Kewirausahaan Sosial dan Pemberdayaan Masyarakat \\ ${ }^{3}$ Pusat Studi CSR, Kewirausahaan Sosial dan Pemberdayaan Masyarakat \\ ${ }^{4}$ Pusat Studi CSR, Kewirausahaan Sosial dan Pemberdayaan Masyarakat \\ *Korespondensi: Soni Ahmad Nulhaqim <soninulhaqim@yahoo.com>
}

\begin{abstract}
The COVID-19 pandemic has an impact on various aspects of society, one of which is the economic aspect. Many of the people have reduced their income and even have lost their income as a result of the COVID-19 pandemic. One of the affected community groups is small business actors in RW 05 Cinunuk Village, Cileunyi District, Bandung Regency. Small business actors in the region are faced with declining sales levels, switching to selling other types of products, and even ceasing their business in this pandemic. Facing these conditions, these small business actors are trying to do online marketing to increase their income again. The problem that then arises is that most of these small business actors do not yet have sufficient knowledge and skills in marketing online. Through the PPM activities integrated with the Virtual KKN, the Team took the initiative to carry out online marketing capacity building activities in the form of training. The target group of this activity is small business actors affected by the COVID-19 pandemic conditions in RW 05 Cinunuk Village, Cileunyi Subdistrict, Bandung Regency and several KKN student domicile locations. The purpose of this PPM activity is to provide knowledge, understanding and skills for target groups in marketing online. The method of implementation is carried out through the preparation stage, the assessment stage, the plan of treatment stage, the treatment stage and the monitoring, evaluation and reporting stage. The results of this activity are the collection of data on the profiles of small business actors affected by the pandemic in RW 05 Cinunuk Village and KKN locations, increased knowledge, understanding and skills of the target group in online marketing and target groups can do online marketing in developing their business.
\end{abstract}

Keywords: COVID-19 pandemic, small business, online marketing.

\begin{abstract}
ABSTRAK
Pandemi COVID-19 membawa dampak pada berbagai aspek kemasyarakatan salah satunya aspek ekonomi. Banyak diantara masyarakat yang berkurang pendapatannya bahkan adapula yang kehilangan pendapatan akibat dari pandemi COVID-19 ini. Salah satu kelompok masyarakat yang terdampak yaitu para pelaku usaha kecil di RW 05 Desa Cinunuk, Kecamatan Cileunyi, Kabupaten Bandung. Para pelaku usaha kecil di wilayah tersebut dihadapkan pada menurunnya tingkat penjualan, beralih berjualan jenis produk lain, bahkan terhenti usahanya pada kondisi pandemi ini. Menghadapi kondisi tersebut para pelaku usaha kecil ini berusaha untuk melakukan pemasaran online untuk kembali meningkatkan pendapatan mereka. Masalah yang kemudian muncul yaitu sebagian besar para pelaku usaha kecil ini belum memiliki pengetahuan serta keterampilan yang cukup dalam melakukan pemasaran secara online. Melalui kegiatan PPM yang terintegrasi dengan KKN Virtual ini Tim berinisiatif untuk melakukan kegiatan peningkatan kapasitas dalam pemasaran online dalam bentuk pelatihan. Kelompok sasaran dari kegiatan ini yaitu para pelaku usaha kecil yang terdampak kondisi pandemi COVID-19 di RW 05 Desa Cinunuk Kecamatan Cileunyi Kabupaten Bandung dan beberapa lokasi domisili mahasiswa KKN. Tujuan dari kegiatan PPM ini yaitu untuk memberikan pengetahuan, pemahaman dan keterampilan bagi kelompok sasaran dalam melakukan pemasaran secara online. Metode pelaksanaan dilakukan melalui tahap persiapan, tahap assessment, tahap plan of treatment, tahap treatment dan tahap monitoring, evaluasi dan reporting. Hasil dari
\end{abstract}


kegiatan ini yaitu didapatnya data mengenai profil pelaku usaha kecil terdampak pandemi di RW 05 Desa Cinunuk dan lokasi KKN, meningkatnya pengetahuan, pemahaman dan keterampilan kelompok sassaran dalam melakukan pemasaran secara online serta kelompok sasaran dapat melakukan pemasaran secara online dalam pengembangan usaha mereka.

Kata Kunci: pandemi COVID-19, usaha kecil, pemasaran online.

\section{PENDAHULUAN}

Pandemi COVID-19 di Indonesia telah berlangsung selama hampir 1 tahun. Berdasarkan data Satuan Tugas Penangangan COVID-19, hingga tanggal 8 Februari 2021, tercatat 1.166 .079 orang terkonfirmasi positif, 963.028 orang sembuh dan 131.763 meninggal dunia akibat COVID-19 ini (https://covid19.go.id/). Adanya kondisi pandemi COVID-19 ini, pada dasarnya tidak hanya berdampak pada aspek kesehatan masyarakat saja, namun juga pada berbagai aspek kemasyarakatan lainnya seperti ekonomi, sosial, agama, budaya, pendidikan, hingga politik.

Berada pada kondisi pandemi, masyarakat dihadapkan pada berbagai dinamika. Terlebih ketika pemerintah mengeluarkan berbagai kebijakan untuk menanganani pandemi COVID-19 ini, semua aspek kemasyarakatan mengalami dampak perubahan yang sangat signifikan. Kebijakan penanganan COVID-19 seperti Pembatasan Sosial Berskala Besar (PSBB) atau yang saat ini dikenal dengan istilah Pemberlakuan Pembatasan Kegiatan Masyarakat (PPKM) yang dikeluarkan pemerintah dengan tujuan untuk menghambat dan memutus mata rantai penyebaran COVID19 menyebabkan masyarakat harus beradaptasi dengan menerapkan kondisi normal baru (Azanella, 2020; Ristyawati, 2020; Nurdiana, 2021). Pada kondisi normal baru, masyarakat diharuskan selalu menerapkan protokol kesehatan serta diharuskan beradaptasi dengan berbagai pembatasan aktivitas dan mobilitas.

Adanya adaptasi kebiasaan baru ini memaksa beragam aspek kemasyarakatan juga harus mengalami penyesuaian. Salah satunya yaitu pada aspek ekonomi masyarakat. Dalam melakukan aktivitas ekonomi terutama aktivitas mata pencaharian, masyarakat mengalami perubahan baik pada sektor formal maupun informal. Pada sektor formal, sebagian masyarakat diwajibkan untuk work from home secara penuh maupun kombinasi antara work from home dan work from office. Pada sektor formal juga ditemukan pekerja yang mengalami Pemutusan Hubungan Kerja (PHK). Berdasarkan data dari KADIN Indonesia pada awal Oktober 2020 lalu, sebanyak 6,4 juta orang pekerja di PHK (Maarif, 2020).

Sementara itu, sektor informal juga merasakan dampak yang sama, banyak masyarakat yang bekerja pada sektor informal berkurang pendapatannya bahkan ada pula yang kehilangan mata pencaharian. Dalam hal ini, salah satu kelompok masyarakat yang terdampak yaitu mereka yang bekerja pada sektor UMKM (Usaha Mikro, Kecil dan Menengah). Berdasarkan data dari Komite Nasional Ekonomi dan Keuangan Syariah pada September 2020, tercatat sebanyak $72,6 \%$ UMKM di Indonesia terdampak pandemi COVID-19 (Miftahudin, 2020). Sementara itu, 48,6\% UMKM dilaporkan gulung tikar pada bulan November 2020 (Zuraya, 2020).

Disisi lain meskipun terdapat UMKM yang terdampak dan gulung tikar, dalam kondisi pandemi ini, juga terdapat UMKM baru yang justru mulai bermunculan (Pamungkas, 2020; Rahma, 2020; Dinnata, 2020). Para pelaku UMKM baru ini sebagian besar merupakan para pekerja yang mengalami PHK yang beralih menjadi wirausahawan serta para kaum milenial yang memanfaatkan waktu ditengah PSBB untuk melakukan aktivitas usaha. Sebagian besar para pelaku UMKM baru ini memanfaatkan media digital dalam pengembangan usaha mereka terutama pada aspek pemasaran (Wardyah, 2020). Pemanfaatan media digital dalam pengembangan usaha ini menjadi salah satu alternatif bagi para pelaku UMKM ditengah kondisi pandemi.

Fenomena seperti yang dijelaskan dimuka dapat ditemukan pada banyak kelompok 
masyarakat. Salah satunya yaitu pada masyarakat RW 05 Desa Cinunuk Kecamatan Cileunyi Kabupaten Bandung. Sebagian warga RW 05 Desa Cinunuk bekerja pada sektor informal seperti buruh harian lepas, tukang ojeg, tukang bangunan, pedagang kecil, dan lain sebagainya (Profil RW 05 Desa Cinunuk, Kec. Cileunyi, Kab. Bandung Tahun 2020). Adanya kebijakan penanganan COVID-19 yang dikeluarkan oleh pemerintah (kebijakan social distancing, physical distancing dan PSBB) menyebabkan pendapatan warga yang bekerja pada sektor informal ini menjadi berkurang. Bahkan ada diantara mereka yang kehilangan sumber pendapatan.

Ditengah kesulitan akibat pandemi, terdapat anggota masyarakat yang melakukan kegiatan ekonomi produktif melalui aktivitas usaha. Aktivitas wirausaha yang dilakukan oleh warga RW 05 Desa Cinunuk ini baik usaha yang telah dilakukan sejak lama maupun berbagai jenis usaha baru yang muncul ketika kondisi pandemi COVID-19. Dalam melakukan aktivitas wirausaha ditengah kondisi pandemi COVID-19, warga RW 05 Desa Cinunuk mengalami berbagai kendala, salah satunya yaitu kendala dalam bidang pemasaran. Kondisi pandemi mengakibatkan proses pemasaran produk menjadi terhambat. Dalam kondisi pandemi ini para pelaku usaha tidak dapat memasarkan produk mereka secara optimal karena adanya berbagai kebijakan pengurangan aktivitas sosial. Hal ini mengakibatkan tingkat penjualan produk menjadi menurun. Hal ini dirasakan oleh seluruh jenis usaha baik usaha baru maupun jenis usaha yang telah dilakukan sejak lama.

Menanggapi masalah kesulitan dalam hal pemasaran tersebut, beberapa pelaku usaha mencoba memasarkan produk mereka secara online baik melalui media sosial maupun melalui berbagai marketplace. Hal ini rupanya tidak langsung menyelesaikan permasalahan yang ada. Masalah yang kemudian muncul yaitu sebagian besar para pelaku usaha di RW 05 Desa Cinunuk tersebut belum memiliki pengetahuan serta keterampilan yang cukup dalam melakukan pemasaran secara online. Merespon kondisi tersebut, melalui kegiatan
PPM yang terintegrasi dengan KKN Virtual ini Tim Pelaksana PPM melakukan kegiatan Peningkatan Kapasitas dalam Pemasaran Online Bagi Pelaku Usaha Kecil yang Terdampak Kondisi Pandemi COVID-19 di RW 05 Desa Cinunuk Kec. Cileunyi Kab. Bandung. Metode yang dilakukan dalam PPM ini yaitu dalam bentuk pelatihan. Selain di RW 05 Desa Cinunuk, pelatihan juga diadakan secara virtual dengan sasaran para pelaku usaha kecil yang menjadi mitra mahasiswa KKN di lokasi domisilinya masing-masing.

Tujuan dari kegiatan PPM ini yaitu untuk memberikan pengetahuan dan keterampilan bagi para pelaku usaha kecil yang terdampak kondisi COVID- 19 dalam melakukan pemasaran secara online. Bentuk kegiatan yang dilakukan yaitu berupa pelatihan dengan menghadirkan narasumber yang ahli dalam bidang pemasaran online serta para pelaku usaha kecil yang telah berhasil melakukan pemasaran secara online baik yang berasal dari warga RW 05 maupun di luar warga RW 05. Harapannya melalui kegiatan ini pengetahuan dan keterampilan pemasaran online para pelaku usaha kecil di RW 05 Desa Cinunuk dapat lebih meningkat. Berbagai pengetahuan dan keterampilan pemasaran online tersebut juga diharapkan dapat diimplementasikan para praktik usaha yang mereka lakukan.

Adapun salah satu semangat utama dari PPM ini adalah tetap mengobarkan semangat kewirausahaan, yaitu membangun generasi bangsa yang bersemangat tinggi dalam inovasi, pantang menyerah, kreatif dan inovatif serta terampil merangkai solusi dari beragam permasalahan (Wibowo \& Nulhaqim, 2015)

\section{METODE}

Metode utama pelaksanaan dalam kegiatan PPM yang berjudul Peningkatan Kapasitas dalam Pemasaran Online Bagi Pelaku Usaha Kecil yang Terdampak Kondisi Pandemi COVID-19 di RW 05 Desa Cinunuk Kec. Cileunyi Kab. Bandung ini adalah pelatihan. Pelatihan diadakan secara virtual dengan sasaran para pelaku usaha kecil di RW 05 Desa Cinunuk dan para pelaku usaha kecil yang 
menjadi mitra mahasiswa KKN di lokasi domisilinya masing-masing. Mitra mahasiswa KKN ini tersebar di beberapa kota dan kabupaten yaitu di Kota Bandung, Kabupaten Bandung, Kabupaten Sumedang, Kabupaten Subang, Kabupaten Karawang, Kabupaten Cirebon, Kabupaten Pangandaran, Kabupaten Bogor, Kota Bogor, Kota Bekasi, Kota Depok, Kota Jakarta Timur, Kota Tangerang, Kota Tangerang Selatan, Kabupaten Sleman Yogyakarta, Kota Padang Panjang Sumatera Barat,

Goldstsein dan Gressner (1988) dalam Wibowo (2020) mendefinisikan pelatihan sebagai usaha sistematis untuk menguasai keterampilan, peraturan, konsep, ataupun cara berperilaku yang berdampak pada peningkatan kinerja. Selanjutnya menurut Robert dan Dearden (1990) dalam Wibowo et al., (2020) yang menyatakan bahwa pelatihan pada sebagai puncak kegiatan, dilakukan pelatihan yang disampaikan secara tatap maya kepada para pelaku usaha kecil yang menjadi kelompok sasaran.

\section{HASIL DAN PEMBAHASAN}

Kegiatan PPM berupa Peningkatan Kapasitas dalam Pemasaran Online Bagi Pelaku Usaha Kecil yang Terdampak Kondisi Pandemi COVID-19 di RW 05 Desa Cinunuk Kec. Cileunyi Kab. Bandung dan di lokasi domisili mahasiswa KKN ini dilakukan melalui lima tahapan utama yaitu tahap persiapan, tahap assessment, tahap plan of treatment, tahap treatment dan tahap monitoring, evaluasi dan terminasi.

Berikut ini merupakan grafik yang menunjukkan ringkasan proses pelaksanaan kegiatan PPM.

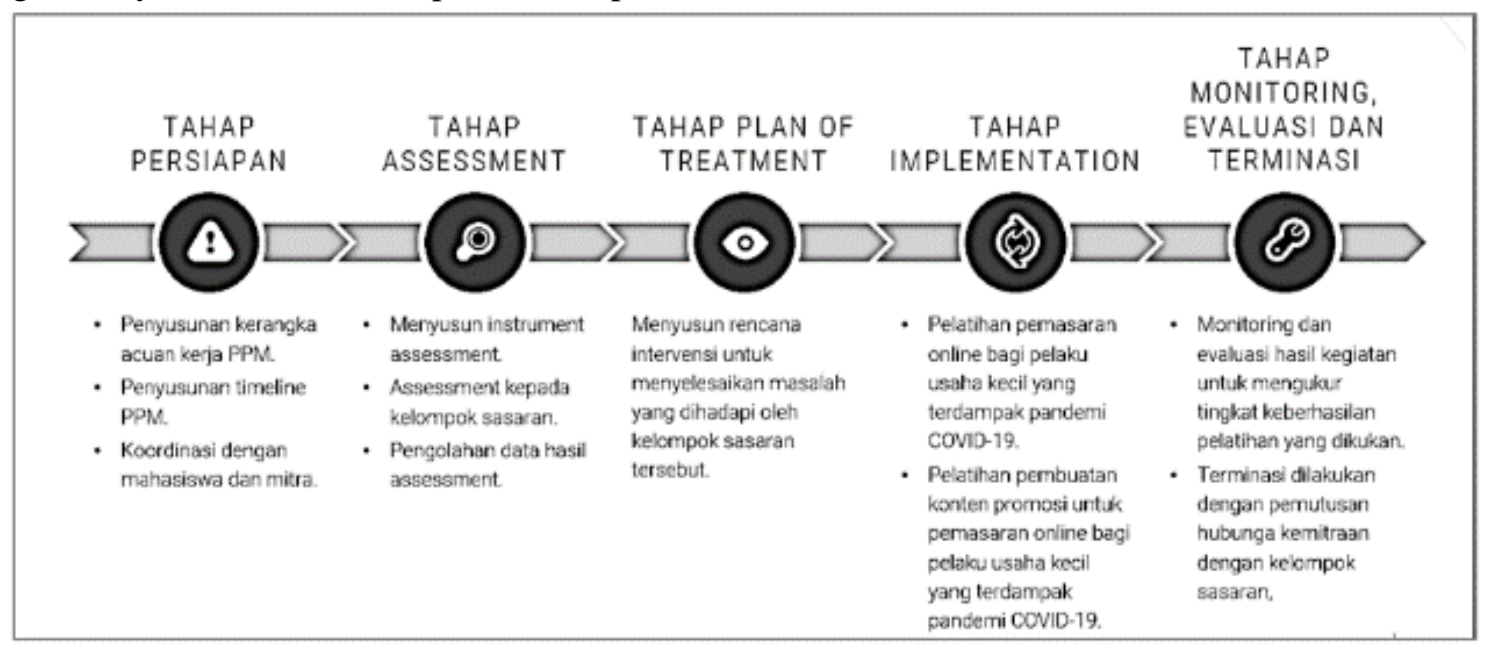

Grafik 1. Ringkasan Proses Pelaksanaan Kegiatan PPM.

Sumber: Tim KKN/PPM Pemasaran Online Desa Cinunuk, 2021.

dasarnya meliputi proses belajar mengajar dan latihan bertujuan untuk mencapai tingkatan kompetensi tertentu atau efisiensi kerja. Namun demikian, sebelum sampai pada metode utama tersebut, dilakukan sejumlah aktivitas penunjang yang dilaksanakan secara tatap muka (luring) ataupun tatap maya (daring).

Kegiatan PPM dilaksanakan melalui tahap persiapan, tahap assessment, tahap plan of treatment, tahap treatment dan tahap monitoring, evaluasi dan reporting. Setiap tahapan kegiatan dilakukan melalui kolaborasi antara dosen dengan mahasiswa. Setelah itu,

\section{Tahap Persiapan}

Pada tahap persiapan, tim pelaksana PPM melakukan beberapa kegiatan yaitu mulai dari penyusunan kerangka acuan kerja PPM, penyusunan timeline PPM, koordinasi dengan mahasiswa, serta koordinasi dengan tokoh masyarakat dan para pelaku usaha kecil yang terdampak COVID-19 baik yang berada di RW 05 Desa Cinunuk maupun mitra yang berada di lokasi domisili mahasiswa KKN.

Penyusunan kerangka acuan kerja PPM dilakukan oleh Tim Pelaksana PPM. Kerangka acuan kerja ini menjadi pedoman bagi tim 
pelaksana atas kegiatan yang akan dilaksanakan dalam kegiatan PPM. Kerangka acuan kerja ini juga diberikan kepada mahasiswa dan kelompok sasaran agar mendapatkan gambaran umum terhadap kegiatan PPM yang akan dilaksanakan. Selain menyusun kerangka acauan kerja, tim pelaksana PPM juga menyusun timeline kegiatan PPM. Timeline ini disusun dengan tujuan agar tim pelaksana memiliki acuan kegiatan PPM pada setiap minggunya.

Koordinasi dengan mahasiswa dilakukan secara daring baik melalui grup whatsapp, google meet maupun zoom meeting. Koordinasi ini dilakukan dengan tujuan agar mahasiswa dapat mengetahui gambaran umum kegiatan PPM yang akan dilakukan serta dapat melakukan pembagian tugas dan peran dalam kegiatan PPM yang akan dilakukan. Sementara itu, koordinasi dengan mitra yaitu tokoh masyarakat dan pelaku usaha kecil yang terdampak COVID-19 di RW 05 Desa Cinunuk dilakukan oleh Ketua Tim Pelaksana PPM di lingkungan domisilinya. Sementara koordinasi dengan mitra di lokasi domisili mahasiswa KKN dilakukan oleh para mahasiswa secara langsung. Koordinasi ini dilakukan dengan tujuan agar kelompok sasaran juga mengetahui kegiatan PPM yang akan dilakukan.

\section{Tahap Assessment}

Tahap assessment dimulai dengan menyusun instrument assessment yang akan digunakan untuk menggali data terkait dengan masalah yang dihadapi oleh kelompok sasaran. Penyusunan instrument assessment dilakukan melalui diskusi antara tim pelaksana PPM dengan mahasiswa secara daring. Setelah instrument assessment disepakati, langkah selanjutnya yaitu mahasiswa melakukan assessment kepada kelompok sasaran. Assessment ini dilakukan dengan teknik wawancara mendalam secara daring melalui aplikasi whatsapp.

Setelah assessment dilakukan, data yang terkumpul kemudian diolah. Berdasarkan hasil pengolahan data assessment ini diperoleh gambaran kondisi yang dihadapi oleh kelompok sasaran. Berikut ini merupakan masalah utama yang dihadapi oleh kelompok sasaran, antara lain yaitu:

a. Pelaku usaha kecil di RW O5 Desa Cinunuk terdampak kondisi pandemi COVID-19 khususnya yang berada di RT 01 dan RT 02 dengan pertimbangan mudah diakses saat pandemi. Selain itu, para pelaku usaha kecil yang menjadi mitra mahasiswa KKN juga merasakan dampak dari pandemi COVID-19.

b. Tingkat penjualan para pelaku usaha kecil baik yang berada di RW 05 Desa Cinunuk maupun para pelaku usaha kecil yang menjadi mitra mahasiswa KKN selama pandemi mengalami pengurangan karena terbatasnya akses pemasaran akibat adanya PSBB dan PPKM.

c. Jenis pelaku usaha kecil yang menjadi sasaran dalam PPM yang berada di RW 05 Desa Cinunuk meliputi pedagang baso tahu, bubur, nasi tutug oncom dan nasi uduk, gurame pepes dan acar kuning, ayam mide, mie ayam, seblak, lumpia basah serta aneka kue jajanan rakyat. Sementara itu, jenis usaha yang dilakukan oleh mitra mahasiswa KKN meliputi usaha kuliner dan catering (kopi, kue, roti, frozen foods, ketoprak, nasi uduk, ayam goreng, keripik, martabak, seblak, bakso cuanki dan kwetiaw) serta jenis usaha fashion dan aksesoris (masker handmade, masker wajah, ikat rambut dan kaos clothing).

d. Untuk meningkatkan kembali penjualan, para pelaku usaha kecil di RW 05 Desa Cinunuk dan para pelaku usaha kecil yang menjadi mitra mahasiswa KKN ini berupaya melakukan pemasaran secara online, namun hal ini belum mampu dilakukan secara optimal karena pengetahuan, pemahaman dan keterampilan mereka dalam melakukan pemasaran secara online masih sangat terbatas.

\section{Tahap Plan of Treatment}

Setelah diperoleh gambaran kondisi yang dihadapi oleh kelompok sasaran, selanjutnya 
tim pelaksana PPM dan mahasiswa KKN menyusun rencana intervensi untuk menyelesaikan masalah yang dihadapi oleh kelompok sasaran tersebut. Rencana intervensi (plan of treatment) tersebut berupa dua bentuk pelatihan yaitu:

a. Pelatihan Pemasaran Online Bagi Pelaku Usaha Kecil yang Terdampak Pandemi COVID-19; dan

b. Pelatihan Pembuatan Konten untuk Pemasaran Online Bagi Pelaku Usaha Kecil yang Terdampak Pandemi COVID-19.

Kedua bentuk pelatihan ini direncanakan untuk dilakukan secara daring melalui zoom meeting. Narasumber untuk kedua pelatihan tersebut yaitu narasumber yang berasal dari praktisi dan akademisi yang memiliki kompetensi serta pengalaman yang baik dalam melakukan aktivitas pemasaran secara online.

\section{Tahap Treatment}

Tahap treatment ini merupakan tahap pelaksanaan dari kegiatan PPM. Tahap treatment ini juga merupakan tahap pelaksanaan intervensi oleh tim pelaksana PPM terhadap masalah yang dihadapi oleh kelompok sasaran.

Pelatihan pertama yaitu pelatihan pemasaran online bagi pelaku usaha kecil yang terdampak pandemi COVID-19. Bentuk kegiatan yaitu pelatihan. Tujuan dari kegiatan pelatihan pertama ini yaitu memberikan pengetahuan, pemahaman dan keterampilan para pelaku usaha kecil yang terdampak pandemi COVID-19 dalam melakukan pemasaran online. Kelompok sasaran yang menjadi peserta dalam pelatihan ini yaitu pelaku Usaha Kecil yang Terdampak Pandemi COVID-19 di RW 05 Desa Cinunuk dan para pelaku usaha kecil yang menjadi mitra mahasiswa KKN di lokasi domisilinya masingmasing. Pelatihan dilaksanakan pada hari Jumat, 22 Januari 2021 secara daring melalui zoom meeting.

Kegiatan pelatihan ini dilakukan secara daring melalui zoom meeting. Pelatihan diawali dengan pembukaan oleh ketua tim pelaksana PPM (Dr. Soni Akhmad Nulhaqim, S.Sos.,
M.Si) tentang pentingnya mengembangkan usaha dalam masa pandemic sesuai standar protokol kesehatan dan pemasaran online sabagai upaya memperluas konsumen dan mempertahankan keberlangsungan usaha. Kemudian, pelatihan dilanjutkan dengan pamaparan materi oleh para narasumber. Narasumber pertama Ricky P. Ramadhan (Head of Online Distribution Unit Mizan Media Utama) memberikan materi yang berjudul "Developing Digital Marketing Channel". Dalam pemaparannya, narasumber pertama menjelaskan bahwa sektor UMKM merupakan tulang punggung ekonomi nasional. Dalam pengembangannya, sektor UMKM ini memiliki beberapa tantangan, diatanya yaitu:

a. Aspek produksi. Kualitas produk yang masih kurang memadai untuk produksi masal.

b. Aspek Human development. Kurangnya hard skill dan soft skill dalam operasional bisnis.

c. Aspek Marketing. Kurangnya keterampilan pemasaran, penetrasi pasar dan branding.

d. Aspek Distribution. Sulitnya menjaga kesinambungan supply chain dan distribusi pemasaran.

e. Aspek Investment. Sulitnya mendapatkan modal untuk memulai bisnis dan pengelolaan finansial.

Dalam menghadapi tantangan tersebut, perlu dilakukan berbagai upaya pengembangan. Upaya pengembangan tersebut diantaranya:

a. Production. Peningkatan kapasitas produksi melalui pelatihan (BLK). pelatihan pengolahan bahan baku.

b. Human development. Adaptasi penggunaan POS di outlet. penggunaan software pencatatan keuangan.

c. Marketing. Pelatihan digital marketing, branding, pembuatan konten produk dan memanfaatkan jasa influencer.

d. Distribution. Pemasaran via marketplace, retail dan reseller. beberapa UKM sudah mempunyai situs mandiri. 
e. Investment. Kompetisi, inkubasi dan forum investasi. peer to peer lending, pinjaman bank.

Khusus dalam pengembangan pemasaran melalui media digital, narasumber pertama memberikan tips untuk pengembangan digital marketing untuk para pelaku UMKM yaitu:

a. Adaptasi terhadap channel pemasaran digital (marketplace, web mandiri, socmed)

b. Bergabung dengan komunitas, asosiasi dan forum bisnis skala lokal.

c. Meningkatkan kapabilitas sdm dalam mengelola kanal digital

d. Sinergi dengan konsep pentahelix (Academic, Business, Community, Government, Media).

Narasumber kedua yaitu Masriah Budyartin, ia merupakan pelaku UMKM kuliner di RT 01 RW 05 Desa Cinunuk yang telah memanfaatkan pemasaran online dengan jenis makanan berupa seblak, lumpia basah dan bakso aci. Materi yang disampaikan oleh narasumber kedua ini yaitu sharing mengenai pengalamannya dalam memulai dan mengembangkan usaha kulinernya tersebut. Dalam pengembangan usahanya, narasumber memulai usaha tersebut secara rumahan, hingga saat ini ia melakukan pamasaran produknya tersebut secara online seperti pada Instagram, Whatsapp, Gofood, Grabfood dan Shoope.

Narasumber kedua menyebutkan bahwa dalam kondisi pandemi, tingkat penjualan produk usahanya berkurang. Hal ini karena pada kondisi pandemi ini terdapat berbagai pembatasan aktivitas sosial. Pesanan-pesanan melalui aplikasi gofood dan grabfood pun saat ini dibatasi. Padahal sebelumnya penjualan melalui kedua aplikasi tersebut sangat menjadi andalan. Selanjutnya, penjualan melalui media Instagram dan Shoope belum berhasil mendatangkan pembeli karena ia baru memulai membuat akun usaha di kedua platform tersebut selama dua bulan kebelakang. Tantangan selanjutnya yaitu ia ingin mengembangkan Instagram dan Shoope sebagai media pemasaran online produk usahanya.

Narasumber ketiga yaitu Wandi Adiansah, narasumber merupakan Asisten Peneliti Kajian
Resolusi Konflik Pusat Studi CSR, Kewirausahaan Sosial dan Pemberdayaan Masyarakat FISIP Unpad. Materi yang dipaparkan oleh narasumber ketiga berjudul "Social Media Marketing untuk UMKM". Materi ini berisi tips bagi para pelaku UMKM yang ingin memulai melakukan sosial media marketing. Tips yang diberikan berasal dari pengalaman narasumber dalam melakukan media sosial marketing pada usahanya yaitu sebagai reseller produk kopi lokal Jawa Barat. Tips-tips social media marketing tersebut yaitu:

a. Tentukan target konsumen.

b. Gunakan platform yang sesuai dengan target konsumen dan buat akun usaha pada platform tersebut.

c. Bangun brand awareness.

d. Buat konten yang menarik.

e. Jangan hanya promosi tetapi juga aktif bersosialisasi.

f. Konsisten upload pada waktu yang tepat.

g. Ketepatan dan kecepatan pengiriman pesanan.

Narasumber terakhir yaitu Maulana Irfan, S.Sos., M.I.Kom, ia merupakan Dosen Departemen Kesejahteraan Sosial FISIP Unpad. Materi yang dipaparkan oleh narasumber keempat ini berjudul "Online Marketing dalam Pengembangan UMKM". Pada era masyarakat 5.0 peradaban manusia dalam hubungannya dengan teknologi, mencoba membawa kembali peradaban sesungguhnya dalam perkembangan teknologi yang berpusat pada manusia Human Centered Technology Based. Pesatnya perkembangan teknologi, dunia digital dan internet tentu juga berimbas pada dunia pemasaran. Tren pemasaran di dunia beralih dari yang semula konvensional (offline) menjadi digital (online). Strategi online marketing ini lebih prospektif karena memungkinkan para calon pelanggan potensial untuk memperoleh segala macam informasi mengenai produk dan bertransaksi melalui internet. Online marketing ini harus mampu dimanfaatkan oleh para pelaku UMKM di Indonesia.

Hasil dan capaian dari kegiatan pelatihan ini yaitu para peserta pelatihan mendapatkan 
pengetahuan dan pemahaman baru tentang pemasaran online. Para peserta pelatihan juga lebih termotivasi untuk melakukan pemasaran online setelah mendengarkan pemaparan dari narasumber yang sharing pengalaman tentang praktik pemasaran secara online.

Berikut ini merupakan dokumentasi dari pelaksanaan kegiatan pelatihan pemasaran online bagi pelaku usaha kecil yang terdampak pandemi COVID-19. narasumber. Narasumber pertama ini yaitu Heru Arya, ia merupakan Konten Kreator di Instagram dengan username @ heruaryaa. Judul materi narasumber pertama yaitu "Rumus Rahasia Membuat Konten yang Menarik". Dalam membuat konten promosi yang menarik, terdapat 2 hal utama yang harus diperhatikan yaitu membuat konsep desain dan konsep materi. Membuat konsep desain dapat dilakukan dengan membuat coretan-coretan di

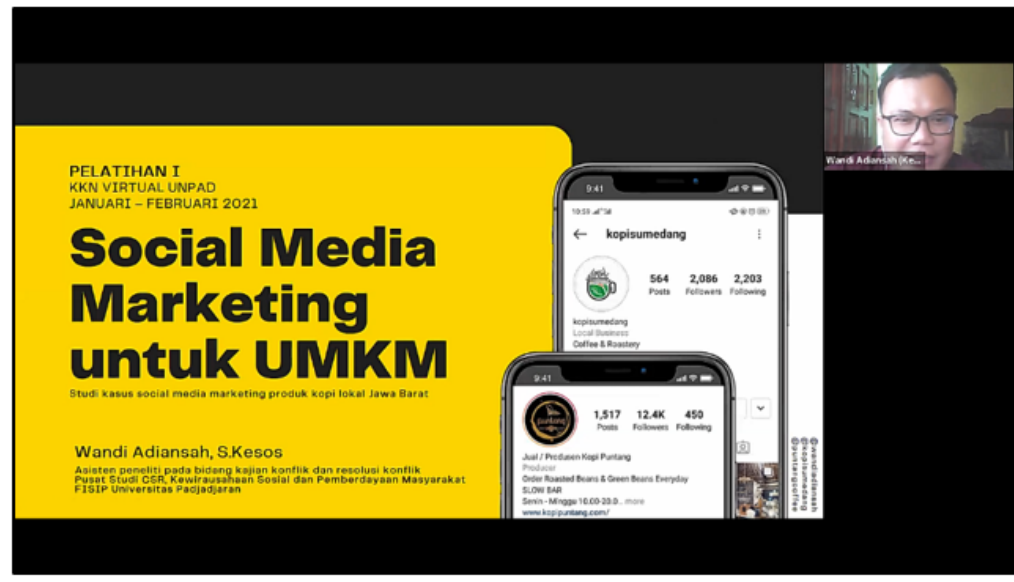

Gambar 1. Dokumentasi Kegiatan Pelatihan Pemasaran Online Bagi Pelaku Usaha Kecil yang Terdampak Pandemi COVID-19.

Sumber: Tim KKN/PPM Pemasaran Online Desa Cinunuk, 2021.

Selanjutnya, pelatihan kedua yaitu pelatihan pembuatan konten promosi untuk pemasaran online bagi pelaku usaha kecil yang terdampak pandemi COVID-19. Tujuan dari kegiatan pelatihan kedua ini yaitu memberikan pengetahuan, pemahaman dan keterampilan para pelaku usaha kecil yang terdampak pandemi COVID-19 dalam membuat konten promosi untuk pemasaran online. Sasaran peserta pelatihan yaitu pelaku Usaha Kecil yang terdampak pandemi COVID-19 di RW 05 Desa Cinunuk dan para pelaku usaha kecil yang menjadi mitra mahasiswa KKN di lokasi domisilinya masing-masing. Kegiatan pelatihan dilakukan secara daring melalui zoom meeting pada hari Senin, 1 Februari 2021.

Pelatihan diawali dengan pembukaan oleh ketua tim pelaksana PPM, Dr. Soni Akhmad Nulhaqim, S.Sos., M.Si yang menyampaikan tentang pentingnya kreasi desain dalam pemasaran online dan belajar dari pelaku usaha yang berpengalaman dan sukses. Pelatihan dilanjutkan dengan pemaparan dari kertas kemudian divisualisasikan melalui aplikasi desain di komputer. Selanjutnya dalam membuat konsep materi sistematika yang harus diperhatikan yaitu judul, paragraph pembuka, isi, ringkasan dan penutup. Dalam pemaparannya, narasumber pertama juga mempraktikan cara membuat desain konten promosi melalui google slide. Para peserta dapat melihat bagaimana proses pembuatan desain konten promosi yang dipraktikan secara langsung oleh narasumber pertama.

Narasumber kedua yaitu Kevin Jeanando T, S.T. Narasumber merupakan Ex-Head of Social Media Manager at Bytedance Indonesia. Judul materi yang dipaparkan yaitu "Apa itu Social Media Marketing?". Social media marketing dapat dilakukan melalui social blogging, social forum, social massaging, social sharring, social networking, social live streaming, dan social dating. Dalam melakukan social media marketing terdapat beberapa strategi yang harus dilakukan yaitu mulai dari audit media sosial, menetapkan sasaran, manganalisis target 
audiens, menentukan strategi konten, menentukan strategi media sosial berbayar dan memantau, mengukur serta mengoptimalkan. Kondisi pandemi yang terjadi saat ini, telah mempercepat transformasi digital. Penjualan online selama pandemi tumbuh sebesar $480 \%$. Hal ini menjadi peluang bagi para pelaku UMKM untuk memanfaatkan strategi social media marketing.

Hasil dan capaian kegiatan yaitu para peserta pelatihan mendapatkan pengetahuan dan pemahaman bagaimana membuat konten promosi yang menarik dan efektif untuk pemasaran secara online.
Ciguruwik dan bersebelahan dengan usaha cakue yang telah memiliki konsumennya banyak. Dengan berpindah tempat usaha dan juga promosi melalui $W A$ dan spanduk yang dipasang di lokasi usahanya, maka penjualan makanan menjadi meningkat semula hanya 10 paket menjadi 25 paket makanan.

Pemanfaatan pemasaran online melalui aplikasi belum dimanfaatkan oleh pelaku usaha disebabkan karena: jumlah paket makanan yang disediakan masih terbatas, pelaku usaha berjualan hanya jam tertentu dan waktu lainnya dimanfaatkan untuk kepentingan keluarga. Jika pelaku UMKM akan melakukan pemasaran

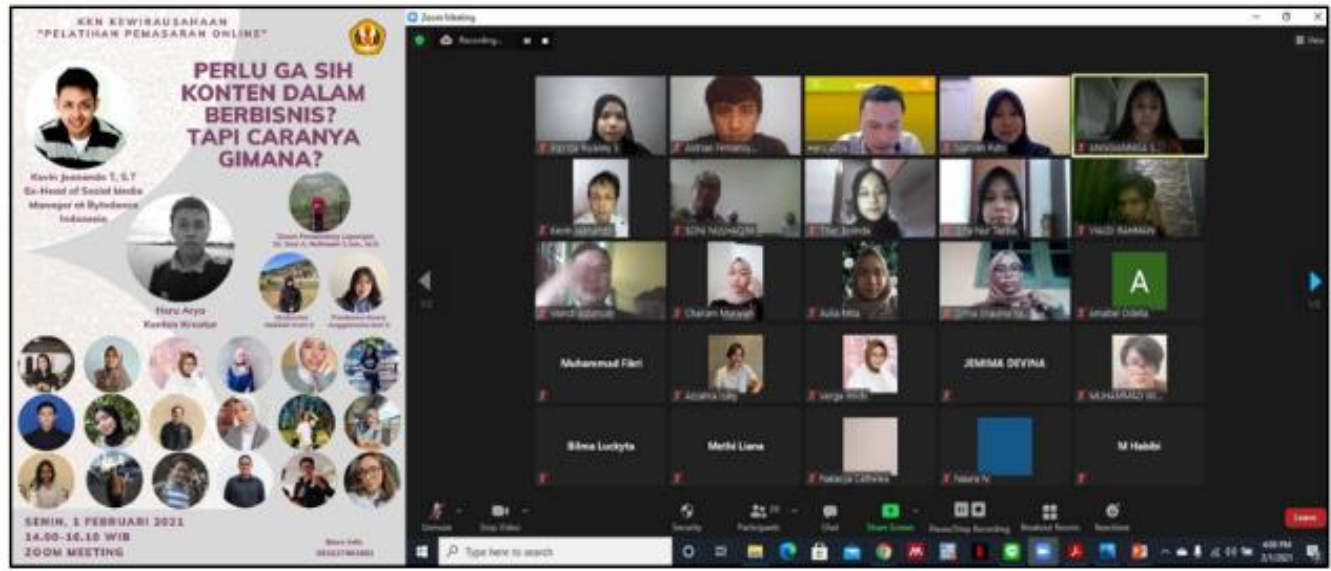

\section{Gambar 2. Dokumentasi Pelatihan Pembuatan Konten Promosi untuk Pemasaran Online Bagi Pelaku Usaha Kecil yang Terdampak Pandemi COVID-19.}

Sumber: Tim KKN/PPM Pemasaran Online Desa Cinunuk, 2021.

\section{Tahap Monitoring, Evaluasi dan Terminasi}

Setelah tahap treatment dilakukan, tim pelaksana PPM dan mahasiswa KKN melakukan monitoring terhadap pemasaran online yang dilakukan oleh kelompok sasaran. Bagi kelompok sasaran yang berada di RW 05 Desa Cinunuk, beberapa pelaku usaha yang sebelumnya menjadi peserta pelatihan telah melakukan dan mengembangkan pemasaran secara online pada usaha mereka seperti WhatsApp, membuat kreasi desain promosi dan dipasang di tempat jualannya serta dapat berkontak melalui telepon. Sisi lainnya ada pelaku usaha yang berkreasi mencari tempat usaha yang strategis. Pelaku usaha tersebut bergerak dalam usaha makanan yaitu nasi uduk dan nasi tutug oncom yang asalnya berusaha di depan rumahnya, saat ini berjualan di Jalan secara online Melalui aplikasi, maka pendampingannya dilakukan oleh pelaku usaha yang menjadi narasumber dalam pelatihan tersebut dan berdomisili di daerah RT $01 \mathrm{RW}$ 05 Desa Cinunuk.

Perkembangan Pandemi Covid-19 semakin meningkat termasuk di lingkungan RW 05 Desa Cinunuk dan mengakibatkan beberapa warga disekitar RT 01 dan RT 02 terkena pandemik ini, salah satunya, Kepala Desa Cinunuk yang berdomisili di RT 01 RW 05 yang wafat disebabkan Positif Covid19 pada hari Kamis, tanggal 4 Februari 2021. Warga menyampaikan berita duka tersebut dalam berbagai media sosial seperti WhatsApp dan masjid-masjid mengumumkan berita duka tersebut dan berdoa untuk almarhum agar diampuni segala dosanya, diterima amal ibadahnya dan dijadikan 
golongan ahli surga, Berkaitan aktivitas kemasyarakatan, peristiwa ini menjadi pembelajaran tentang pentingnya standar protokol kesehatan dan pendeteksian kontak dengan almarhum. Selain itu, bagi pelaku usaha, kejadian tersebut, semakin memperkuat pentingya pemasaran online produk UMKM untuk mengendalikan Interaksi antar warga secara langsung.

Sementara itu, hasil monitoring dan evaluasi yang dilakukan terhadap para pelaku usaha kecil yang menjadi mitra mahasiswa KKN menunjukkan bahwa, kelompok sasaran telah mempraktikan pemasaran secara online untuk menjual produk mereka. Pemasaran secara online ini dilakukan baik melalui media sosial (Whatsapp, Facebook dan Instagram) maupun melalui marketplace seperti Shoppe dan Tokopedia. Pemasaran online yang dilakukan telah berhasil menaikan kembali tingkat penjualan secara bertahap.

Terminasi dari kegiatan PPM bagi kelompok sasaran di RW 05 Desa Cinunuk dirujuk pada organisasi lokal sebagai wadah beraktivitas pelaku usaha. Lembaga yang akan menindaklanjuti pengembangan UMKM adalah organisasi keagamaan di tingkat lokal yaitu DKM Taman Surga Al Ikhlas, Dasar pertimbangannya adalah pelaku usaha UMKM yang mengikuti kegiatan pelatihan adalah semuanyanya muslim, mereka beraktivitas keagamaan berupa pengajian rutin malam jumat dan malam minggu, dan DKM tersebut memiliki program pengembangan usaha ekonomi produktif bagi warga dilingkungan setempat. Sementara itu, terminasi bagi kelompok sasaran yang menjadi mitra mahasiswa KKN dilakukan dengan pemutusan kontrak mitra karena kelompok sasaran dianggap telah mampu melakukan pemasaran online secara mandiri.

\section{KESIMPULAN DAN SARAN}

\section{Kesimpulan}

Berdasarkan uraian diatas, simpulan dari kegiatan "Peningkatan Kapasitas dalam Pemasaran Online Bagi Pengembangan Usaha
Kecil Bagi Warga Terdampak Kondisi Pandemi COVID-19" ini yaitu sebagai berikut:

a. Tahap persiapan.

Kegitan yang dilakukan yaitu penyusunan kerangka acuan kerja PPM, penyusunan timeline PPM, koordinasi dengan mahasiswa, serta koordinasi dengan tokoh masyarakat dan kelompok sasaran.

b. Tahap Assessment.

Kegiatan yang dilakukan yaitu penyusunan instrument, assessment kepada kelompok sasaran, pengolahan data hasil assessment

c. Tahap Plan of Treatment.

Rencana intervensi (plan of treatment) tersebut berupa dua bentuk pelatihan yaitu:

- Pelatihan Pemasaran Online Bagi Pelaku Usaha Kecil yang Terdampak Pandemi COVID19; dan

- Pelatihan Pembuatan Konten untuk Pemasaran Online Bagi Pelaku Usaha Kecil yang Terdampak Pandemi COVID19.

\section{d. Tahap Treatment.}

Tahap treatment yaitu merupakan tahap pelaksanaan pelatihan. Hasil dan capaian dari kedua pelatihan yang telah dilakukan yaitu:

- Hasil dan capaian dari kegiatan pelatihan pertama yaitu para peserta pelatihan mendapatkan pengetahuan dan pemahaman baru tentang pemasaran online. Para peserta pelatihan juga lebih termotivasi untuk melakukan pemasaran online setelah mendengarkan pemaparan dari narasumber yang sharing pengalaman tentang praktik pemasaran secara online .

- Hasil dan capaian kegiatan pelatihan kedua yaitu para peserta pelatihan mendapatkan 
pengetahuan dan pemahaman bagaimana membuat konten promosi yang menarik dan efektif untuk pemasaran secara online.

e. Tahap Monitoring, Evaluasi dan Terminasi.

Hasil monitoring dan evaluasi kegiatan yaitu beberapa pelaku usaha yang sebelumnya menjadi peserta pelatihan telah melakukan dan mengembangkan pemasaran secara online pada usaha mereka. Pemasaran online dilakukan melalui kreasi desain yang dilakukan melalui whatsapp, dan aplikasi. Terminasi kegiatan ini ditindaklanjuti oleh organisasi lokal keagamaan yaitu DKM Taman Surga Al Ikhlas dan pemutusan kontrak kemitraan antara mahasiswa KKN dengan mitra.

Sebagai pelengkap dalam artikel ini, berikut disampaikan pula penyampaian audiovisiual pada saat pelatihan tersebut :

https://us02web.zoom.us/rec/share/TNmG93I7 ukJ2F9P8w3w0oTol2Bn7rjUZrqsZcqBOQZYi EAViAEwoCGxhfmR8jCjQ.nHWUs4tCJQyju $\underline{\mathrm{mxN} \text { ?startTime }=1611298926000}$

Serta pada Link :

https://us02web.zoom.us/rec/share/udKJ0nbJO jckJyp2zRkdm3JAiTImM0iSgWmsuR265_jm tGk_b0fGwwR7-

DcXfk3.BqGc1CepPMcvH3n-

$\underline{\text { ?startTime }=1612162883000}$

\section{Saran}

Berdasarkan kesimpulan diatas, maka terdapat beberapa saran yang dapat diberikan kepada para pelaku usaha kecil yang terdampak COVID-19 baik yang berada di RW 05 Desa Cinunuk maupun bagi para pelaku usaha kecil yang menjadi mitra mahasiswa KKN. Saran tersebut yaitu:

a. Pelaku usaha kecil dapat memanfaatkan pemasaran secara online untuk memasarkan produk usaha mereka dengan terus belajar pada pelaku UMKM yang telah berhasil melaksanakannya.

b. Bagi pemula, bentuk pemasaran online dapat dimulai melalui cara yang sederhana dan mudah dilakukan seperti melalui whatsapp. Berbagai fitur whatsapp dapat dimanfaatkan untuk pemasaran online seperti promosi melalui personal chat, promosi pada whatsapp group, dan promosi melalui story whatsapp.

c. Bagi pelaku usaha yang sebelumnya telah melakukan pemasaran online, dapat mengembangkan strategi pemasaran online produknya dengan mempraktikan berbagai materi pelatihan yang telah diberikan.

\section{DAFTAR PUSTAKA}

Azanella, L. A. (2020, April 13). Apa Itu PSBB hingga Jadi Upaya Pencegahan Covid19? Retrieved from Kompas.com: https://www.kompas.com/tren/read/2020 /04/13/153415265/apa-itu-psbb-hinggajadi-upaya-pencegahan-covid19?page=all\#: :text=PSBB\%20di\%20D KI\%20Jakarta\%20resmi\%20berlaku\%2 Opada\%2010\%20April\%202020.

Dinnata, Regi Yanuar Widhia. Desember, 2020. Dongkrak Ekonomi Saat Pandemi, Sleman Gelar Festival UMKM. Retrived from

https://ayoyogya.com/read/2020/12/01/4 1472/dongkrak-ekonomi-saat-pandemisleman-gelar-festival-umkm

\section{https://covid19.go.id/}

Maarif, Nurcholis. Desember, 2020. 9,77 Juta Orang Kena PHK, MPR Soroti SDM dan Literasi Teknologi. Retrived from https://news.detik.com/berita/d5278957/977-juta-orang-kena-phk-mprsoroti-sdm-dan-literasi-teknologi

Miftahudin, Husen. September, 2020. 72,6\% Pelaku UMKM Terdampak Pandemi. Retrived from https://www.medcom.id/ekonomi/bisnis/ VNx48oBN-72-6-pelaku-umkmterdampak-pandemi 
Nurdiana, T. (2021, Januari 7). Bukan PSBB, pemerintah pakai istilah baru PPKM dalam pembatasan kegiatan, ini bedanya. Retrieved from nasional.kontan.co.id: https://nasional.kontan.co.id/news/bukan -psbb-pemerintah-pakai-istilah-baruppkm-dalam-pembatasan-kegiatan-inibedanya

Pamungkas, Ajar. November, 2020. Menilik Geliat Jumlah UMKM di Indonesia di Masa Pandemi. Retrived from https://majoo.id/blog/detail/menilikgeliat-jumlah-umkm-di-indonesia-dimasa-pandemi

Profil RW 05 Desa Cinunuk, Kec. Cileunyi, Kab. Bandung Tahun 2020.

Rahma, Athika. Desember, 2020. 3 Fokus Menkop Teten Siapkan UMKM Hadapi Pasca Pandemi Covid-19. Retrived from https://www.liputan6.com/bisnis/read/44 32130/3-fokus-menkop-teten-siapkanumkm-hadapi-pasca-pandemi-covid-19

Ristyawati, A. (2020). Efektifitas Kebijakan Pembatasan Sosial Berskala Besar Dalam Masa Pandemi Corona Virus 2019 oleh Pemerintah Sesuai Amanat UUD NRI Tahun 1945. Administrative Law \& Governance Journal, 3(2), 240249. doi:10.14710/alj.v3i2.240-249

Wardyah, Nur Suhra. November, 2020. 450 ribu UMKM baru terdigitalisasi di masa pandemi. Retrived from https://www.antaranews.com/berita/183 9960/450-ribu-umkm-baruterdigitalisasi-di-masa-pandemi

Zuraya, Nidia. November, 2020. Terdampak Covid-19, 48,6 Persen UMKM Indonesia Tutup. Retrived from https://republika.co.id/berita/qjw3nw383 terdampak-covid19-486-persen-umkmindonesia-tutup

Wibowo, Hery \& Nulhaqim, Soni Akhmad. 2015. Kewirausahaan Sosial: Merevolusi Pola Pikir Menginisiasi Mitra Pembangungan. .Jatinangor Sumedang. Penerbit Unpad Press.

Wibowo, H., Rusyidi, B., \& Irfan, M. (2020). Workshop Appreciative Inquiry dan
Pelatihan Kewirausahaan untuk Menbangun Etos Wirausaha Islam Pelaku UMKM Desa Cibodas Kabupaten Bandung. Kumawula: Jurnal Pengabdian Kepada Masyarakat. https://doi.org/10.24198/kumawula.v3i2. 26491 